\title{
Genetic analysis of methicillin-resistant Staphylococcus aureus expressing high- and low- level mupirocin resistance
}

\author{
E. E. UDO, L. E. JACOB and B. MATHEW \\ Department of Microbiology, Faculty of Medicine, Kuwait University, Kuwait
}

\begin{abstract}
Clinical strains of methicillin-resistant Staphylococcus aureus (MRSA) expressing highand low-level mupirocin resistance were studied to determine the genetic location of mupirocin and other resistance determinants. Mupirocin resistance was confirmed by MIC determination with E-test strips. Curing and transfer experiments were used to establish the genetic location of the resistance determinants and the PCR with mupAspecific primers was used to detect the presence of mup $A$ genes. High-level mupirocinresistant isolates had MICs $>1024 \mathrm{mg} / \mathrm{L}$, whereas the low-level resistant isolates had MICs of $32-128 \mathrm{mg} / \mathrm{L}$. The isolates carried plasmids ranging from 2.8 to $38 \mathrm{~kb}$ in size. All of them carried 26- and 3.0-kb plasmids, but only the high-level mupirocin-resistant isolates carried a 38-kb plasmid. Curing and transfer experiments revealed that the 26kb plasmid encoded resistance to cadmium, mercuric chloride, propamidine isethionate and ethidium bromide and the 38-kb plasmid was a conjugative plasmid encoding highlevel mupirocin resistance. One isolate, IBN287, carried both plasmid-borne high-level and chromosomal low-level mupirocin resistance. The mup $A$ gene was detected on the 38-kb plasmid DNA but not in the genomic DNA of the low-level mupirocin-resistant isolates. The genomic DNA of strain IBN287 cured of the 38-kb mupirocin resistance plasmid did not contain mup $A$. The results suggest that different genes encoded low-and high-level mupirocin resistance in these isolates.
\end{abstract}

\section{Introduction}

Mupirocin resistance in Staphylococus aureus is increasing with increasing use of the antibiotic to control the spread of methicillin-resistant S. aureus (MRSA) [1-5]. Two types of mupirocin resistance have been reported to date; a clinically significant high-level resistance (MIC $>512 \mathrm{mg} / \mathrm{L}$ ) and a low-level resistance (MIC 8-256 mg/L) with uncertain clinical significance [2]. High-level mupirocin resistance determinants have been reported to be carried on plasmids that vary in size, restriction patterns and their ability to be transferred in conjugation experiments [6-10]. On the other hand, the determinants for low-level mupirocin resistance are located on the bacterial chromosome [11]. High-level mupirocin resistance is mediated by a mupA gene [12-14] that was previously reported exclusively on mupirocin resistance plasmids [511,15]. However, the mupA gene has also been

Received 14 Feb. 2001; revised version accepted 6 April 2001.

Corresponding author: Dr E. E. Udo (e-mail: EDET@hsc. kuniv.edu.kw). reported in the genomic DNA of a few $S$. aureus isolates expressing low-level mupirocin resistance, suggesting that the тирA gene may also be located in the chromosome $[16,17]$. At present it is not clear whether the chromosomal mupA determinant is widespread and warrants further investigations in staphylococci from different geographical areas.

Mupirocin was introduced for clinical use at the Burns Unit, Ibn Sina Hospital, Kuwait in 1992 but resistance was not detected among $S$. aureus isolated in the unit until Nov. 1996. However, plasmid-borne high-level mupirocin resistance was detected in an isolate of $S$. haemolyticus isolated in the unit in 1995 [15]. From Nov. 1996, MRSA expressing low- and high-level mupirocin resistance were isolated from the Burns Unit. Pulsed-field gel electrophoresis (PFGE) of the mupirocin-resistant and mupirocin-susceptible MRSA from patients revealed that the mupirocin-resistant MRSA had identical or similar pulsed-field patterns to the mupirocin-susceptible MRSA isolated in the unit before the detection of mupirocin resistance. This suggested that a clone of MRSA already present in the Burns Unit had acquired the mupirocin resistance 
plasmid which later spread among MRSA isolates from different patients [5]. Following the initial detection of mupirocin resistance, all MRSA isolates from patients in the Burns Unit were screened for mupirocin resistance as part of a nationwide surveillance of MRSA for mupirocin resistance conducted from 1 May to 31 Oct. 1999. The results of susceptibility testing detected mupirocin resistance in $26 \%$ of these MRSA isolates and their pulsed-field patterns were different from those isolated in 1996-1997 [18], indicating that a new MRSA clone had been introduced into the Burns Unit. This study sought to determine the genetic location of antibiotic resistance determinants in the mupirocin-resistant MRSA and also to investigate whether the mupA gene conferred mupirocin resistance in low- and high-level mupirocin-resistant MRSA isolates from the Burns Unit in Kuwait.

\section{Materials and methods}

\section{MRSA isolates}

The properties of the isolates studied are presented in Table 1. A total of 72 MRSA isolates was obtained from patients in the Burns Unit of Ibn Sina Hospital Kuwait, as part of MRSA surveillance between May and Oct. 1999. They consisted of 36 isolates (50\%) that expressed low-level mupirocin resistance and 19 isolates $(26 \%)$ that expressed high-level mupirocin resistance. The isolates selected for this study were single patient isolates and were representatives of the common pulsed-field patterns.

\section{Susceptibility to antimicrobial agents}

Susceptibility to antimicrobial agents was tested by the disk diffusion method on Mueller Hinton agar with commercial antibiotic disks (Oxoid) as described previously [5]. Susceptibility to mupirocin was determined with disks containing $200 \mu \mathrm{g}$ and $5 \mu \mathrm{g}$ of mupirocin. Growth to the edge of the $200-\mu \mathrm{g}$ mupirocin disk indicated high-level resistance while growth within a 14-mm zone of inhibition with the $5-\mu \mathrm{g}$ mupirocin disk indicated low-level resistance. The MIC of mupirocin was determined with E-test strips (AB Biodisk, Solna, Sweden) according to the manufacturer's instructions. Susceptibility to heavy metals and nucleic acid-binding compounds was tested with 6$\mathrm{mm}$ disks impregnated with cadmium acetate $(130 \mu \mathrm{g})$, propamidine isethionate $(50 \mu \mathrm{g})$ and ethidium bromide $(60 \mu \mathrm{g})$. S. aureus strain ATCC 25923 was used as a control strain. Mupirocin powder was a gift from SmithKline Beecham, Worthing.

\section{$\beta$-lactamase production}

$\beta$-Lactamase production was detected with a chromogenic cephalosporin (nitrocefin; Oxoid) according to the manufacturer's instructions.

\section{Plasmid isolation and analysis}

Plasmids were isolated by the cetyltrimethyl ammonium bromide method, separated by agarose gel electrophoresis and sized as described previously [5].

\section{Curing of resistance and plasmids}

Loss of resistance and plasmids was investigated by growing the organisms at $43^{\circ} \mathrm{C}$ overnight and screening single colonies for the loss of resistance by a replica plating method. Colonies that lost antimicrobial resistance were screened for plasmid loss by agarose gel electrophoresis.

\section{Transfer of plasmid and resistance}

Plasmids were transferred in mixed-culture transfer (MCT) and conjugation experiments as described previously $[5,10]$.

\section{$P C R$}

PCR was performed with previously published primers [16]: Mup1 (5'-CCC ATG GCT TAC CAG TTG A-3') and Mup2 (5'-CCA TGG AGC ACT ATC CGA A-3').

Table 1. Properties of $S$. aureus isolates

\begin{tabular}{|c|c|c|c|}
\hline Isolate no. & Relevant properties & Plasmids & Source/reference \\
\hline WBG248 & RN450 & None & 10 \\
\hline WBG541 & $\mathrm{Fa}^{\mathrm{R}} \mathrm{Rf}^{\mathrm{R}}$, mutant of WBG248 & None & 10 \\
\hline XU21 & $\mathrm{Nv}^{\mathrm{R}} \mathrm{Rf}^{\mathrm{R}}$, mutant of $\mathrm{RN} 4220$ & None & 10 \\
\hline WBG1878 & $\mathrm{Fa}^{\mathrm{R}} \mathrm{Rf}^{\mathrm{R}}, \Phi \mathrm{J}$ lysogen of WBG541 & None & 19 \\
\hline IBN238 & mupL $, \mathrm{Cm}^{\mathrm{R}}, \mathrm{Cd}^{\mathrm{R}}, \mathrm{Hg}^{\mathrm{R}}, \mathrm{Pi}^{\mathrm{R}}, \mathrm{Eb}^{\mathrm{R}}$ & $26,4.4,3.0,2.8$ & This paper \\
\hline IBN246 & mupH, $\mathrm{Cm}^{\mathrm{R}}, \mathrm{Cd}^{\mathrm{R}}, \mathrm{Hg}^{\mathrm{R}}, \mathrm{Pi}^{\mathrm{R}} \mathrm{Eb}^{\mathrm{R}}$ & $38,26,4.4,3.0,2.8$ & This paper \\
\hline IBN252 & mupL, $\mathrm{Cm}^{\mathrm{R}}, \mathrm{Cd}^{\mathrm{R}}, \mathrm{Hg}^{\mathrm{R}}, \mathrm{Pi}^{\mathrm{R}}, \mathrm{Eb}^{\mathrm{R}}$ & $26,4.4,3.0,2.8$ & This paper \\
\hline IBN259 & mupH, $\mathrm{Cm}^{\mathrm{S}}, \mathrm{Cd}^{\mathrm{R}}, \mathrm{Hg}^{\mathrm{R}}, \mathrm{Pi}^{\mathrm{R}}, \mathrm{Eb}^{\mathrm{R}}$ & $38,26,3.0,2.8$ & This paper \\
\hline IBN260 & mupH, $\mathrm{Cm}^{\mathrm{R}}, \mathrm{Cd}^{\mathrm{R}}, \mathrm{Hg}^{\mathrm{R}}, \mathrm{Pi}^{\mathrm{R}}, \mathrm{Eb}^{\mathrm{R}}$ & $38,26,4.4,3.0,2.8$ & This paper \\
\hline IBN266 & mupH, $\mathrm{Cm}^{\mathrm{R}}, \mathrm{Cd}^{\mathrm{R}}, \mathrm{Hg}^{\mathrm{R}}, \mathrm{Pi}^{\mathrm{R}}, \mathrm{Eb}^{\mathrm{R}}$ & $38,26,4.4,3.0,2.8$ & This paper \\
\hline IBN267 & mupL, $\mathrm{Cm}^{\mathrm{R}} \mathrm{Cd}^{\mathrm{R}}, \mathrm{Hg}^{\mathrm{R}} \mathrm{Pi}^{\mathrm{R}}, \mathrm{Eb}^{\mathrm{R}}$ & $26,4.4,3.0,2.8$ & This paper \\
\hline IBN269 & mupL, $\mathrm{Cm}^{\mathrm{S}}, \mathrm{Cd}^{\mathrm{R}}, \mathrm{Hg}^{\mathrm{R}}, \mathrm{Pi}^{\mathrm{R}}, \mathrm{Eb}^{\mathrm{R}}$ & $26,3.0,2.8$ & This paper \\
\hline IBN271 & mupL, $\mathrm{Cm}^{\mathrm{S}}, \mathrm{Cd}^{\mathrm{R}}, \mathrm{Hg}^{\mathrm{R}}, \mathrm{Pi}^{\mathrm{R}}, \mathrm{Eb}^{\mathrm{R}}$ & $26,3.0,2.8$ & This paper \\
\hline IBN287 & mupH, $\mathrm{CmR}, \mathrm{Cd}^{\mathrm{R}}, \mathrm{Hg}^{\mathrm{R}}, \mathrm{Pi}^{\mathrm{R}}, \mathrm{Eb}^{\mathrm{R}}$ & $38,26,4.4,3.0,2.8$ & This paper \\
\hline XU320 & IBN246 cured of mupH & $26,4.4,3.0,2.8$ & This paper \\
\hline XU322 & mupL, IBN287 cured of mupH & $26,4.4,3.0,2.8$ & This paper \\
\hline XU305 & IBN252 cured of $\mathrm{Cd}^{\mathrm{R}}, \mathrm{Hg}^{\mathrm{R}}, \mathrm{Pi}^{\mathrm{R}}, \mathrm{Eb}^{\mathrm{R}}$ & $4.4,2.8$ & This paper \\
\hline
\end{tabular}


The primers were purchased from Gibco BRL Custom primers (Life Technologies, UK). Amplification was performed with a kit from Gibco BRL. The amplification mixture consisted of $45 \mu \mathrm{l}$ of Supermix $(22 \mathrm{mM}$ Tris-HCl, pH 8.4; $55 \mathrm{mM} \mathrm{KCl,} 1.65 \mathrm{mM} \mathrm{MgCl} 2,220 \mathrm{M}$ dGTP, $220 \mathrm{M}$ dATP, $220 \mathrm{M}$ dCTP, recombinant Taq DNA polymerase $22 \mathrm{U} / \mathrm{ml}$ ), bacterial DNA $3 \mu \mathrm{l}$, primer solution $2 \mu \mathrm{l}$ in a total volume $50 \mu \mathrm{l}$. A Perkin Elmer 9600 Thermocycler (Perkin Elmer, Cetus Norwalk, CT, USA) was programmed for 32 cycles with the following parameters: denaturation at $94^{\circ} \mathrm{C}$ for $3 \mathrm{~min}$, annealing at $60^{\circ} \mathrm{C}$ for $45 \mathrm{~s}$, extension at $72^{\circ} \mathrm{C}$ for $1 \mathrm{~min}$ and final extension at $72^{\circ} \mathrm{C}$ for $2 \mathrm{~min}$. Amplified products were examined by agarose gel electrophoresis with agarose $1.5 \% \mathrm{w} / \mathrm{v}$ in $1 \times \mathrm{TAE}$ buffer for $2 \mathrm{~h}$ at $70 \mathrm{~V}$.

\section{Results}

The 10 isolates investigated in this study were representatives of 55 mupirocin-resistant MRSA isolated between May and Oct. 1999 and consisted of five high-level and five low-level mupirocin-resistant isolates. The high-level resistant isolates had MIC values $>1024 \mathrm{mg} / \mathrm{L}$ and belonged to two related pulsed-field patterns. The mupirocin MICs for the low-level resistant isolates ranged from 32 to $128 \mathrm{mg} / \mathrm{L}$ and these isolates belonged to three closely related pulsedfield patterns (not shown). All produced $\beta$-lactamase and were resistant to penicillin $G$, gentamicin, kanamycin, tobramycin, ciprofloxacin, tetracycline, cadmium, mercuric chloride, propamidine isethionate and ethidium bromide, but differed in their resistance to erythromycin, chloramphenicol and fusidic acid, as shown in Table 1. They harboured three-to-five plasmids per cell with sizes ranging from $2.8 \mathrm{~kb}$ to $38 \mathrm{~kb}$ (Table 1). All carried a 26-kb and a 3.0-kb plasmid but differed in the carriage of the 38-, 4.4- and 2.8-kb plasmids (Fig. 1). The $38-\mathrm{kb}$ plasmid was present only in the high-level mupirocin-resistant isolates.

\section{Location of resistance determinants}

To isolate the plasmids and determine their resistance phenotypes, the high-level mupirocin-resistant isolates IBN246, IBN259, IBN260 and IBN287 and the lowlevel mupirocin-resistant isolates, IBN252, IBN267 and IBN271, were selected and used in curing and transfer experiments. In curing experiments, resistance to cadmium, mercuric chloride, propamidine isethionate and ethidium bromide were lost together from all the isolates whether they expressed low- or high-level mupirocin resistance and their loss was accompanied by the loss of a $26-\mathrm{kb}$ plasmid in the colonies screened. Mupirocin resistance was lost from the high-level resistant isolates, IBN246 and IBN287; high-level mupirocin resistance was lost together with the $38-\mathrm{kb}$ plasmid in both isolates. A colony of strain IBN246

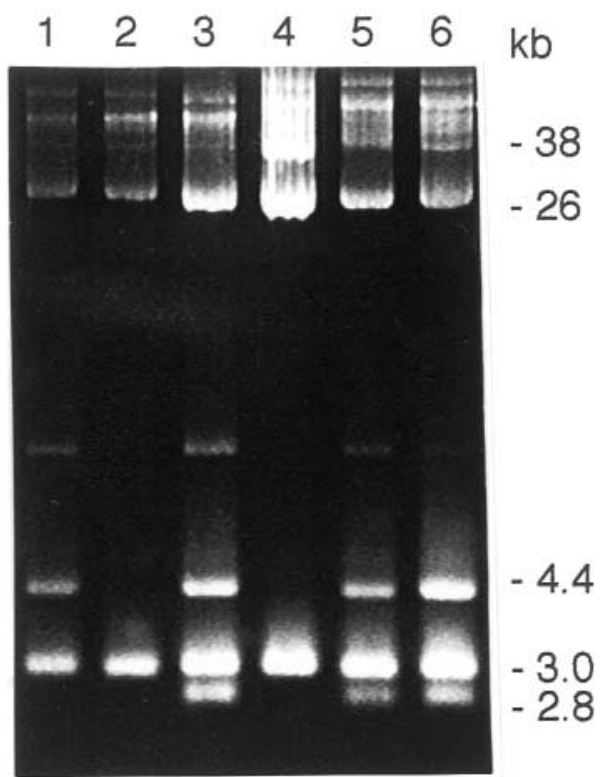

Fig. 1. Plasmid contents of representative mupirocinresistant MRSA. Lanes 1-3, MRSA isolates expressing low-level mupirocin resistance, they lack the $38-\mathrm{kb}$ plasmid; 4-6, MRSA isolates expressing high-level mupirocin resistance, they carry the $38-\mathrm{kb}$ plasmid.

cured of the 38-kb plasmid and mupirocin resistance had a mupirocin MIC of $2 \mathrm{mg} / \mathrm{L}$ and was designated XU320. The loss of the $38-\mathrm{kb}$ plasmid in strain IBN287 resulted in colonies that still expressed lowlevel mupirocin resistance. One such colony, designated XU322, had a mupirocin MIC of $64 \mathrm{mg} / \mathrm{L}$.

\section{Transfer of resistance determinants}

Each of the 10 isolates was used as a donor in separate conjugation and MCT experiments to transfer the plasmids to recipient strains and confirm the plasmid location of the cured resistance determinants. Results of the transfer experiments are summarised in Table 2. Chloramphenicol and high-level mupirocin resistance were transferred in both conjugation and MCT experiments. In the conjugation experiments, transconjugants were obtained on mupirocin and chloramphenicol selection plates. Those obtained on mupirocin selection plates were either resistant to mupirocin or to mupirocin and chloramphenicol. Colonies resistant to mupirocin carried a $38-\mathrm{kb}$ plasmid or a $38-\mathrm{kb}$ plasmid and a 3.0 - or $2.8-\mathrm{kb}$ plasmid. Colonies resistant to mupirocin and chloramphenicol carried a 38- and a 4.4-kb plasmid as shown in Table 2 and Fig. 2. Transconjugants from the chloramphenicol selection plates were also either resistant to chloramphenicol or to chloramphenicol and mupirocin, with plasmid profiles similar to those found in transconjugants from mupirocin selection plates.

Resistance to mupirocin, chloramphenicol, cadmium, mercuric chloride, propamidine isethionate and ethidium bromide was transferred in MCT experiments. Results of MCT for mupirocin and chloramphenicol 
Table 2. Transfer of resistance determinants from high- and low-level mupirocin-resistant MRSA

\begin{tabular}{|c|c|c|c|c|}
\hline Isolate no. & $\begin{array}{l}\text { Mupirocin } \\
\text { resistance }\end{array}$ & $\begin{array}{l}\text { Mode of } \\
\text { transfer }\end{array}$ & $\begin{array}{l}\text { Resistance } \\
\text { transferred }\end{array}$ & $\begin{array}{l}\text { Plasmid } \\
\text { transferred }(\mathrm{kb})\end{array}$ \\
\hline \multirow[t]{3}{*}{ IBN246 } & \multirow[t]{3}{*}{ High-level } & $\mathrm{MCT}$ & Mup, Cm & $38,4.4$ \\
\hline & & MCT & $\mathrm{Cm}$ & 4.4 \\
\hline & & MCT & $\mathrm{Cd}, \mathrm{Hg}, \mathrm{Pi}, \mathrm{Eb}$ & 26 \\
\hline \multirow[t]{4}{*}{ IBN246 } & \multirow[t]{4}{*}{ High-level } & $\mathrm{C}$ & Mup,Cm & $38,4.4,2.8$ \\
\hline & & $\mathrm{C}$ & Mup, Cm & $38,4.4$ \\
\hline & & $\mathrm{C}$ & Mup & 38 \\
\hline & & $\mathrm{C}$ & $\mathrm{Cm}$ & 4.4 \\
\hline IBN252 & Low-level & MCT & $\mathrm{Cd}, \mathrm{Hg}, \mathrm{Pi}, \mathrm{Eb}$ & 26 \\
\hline \multirow[t]{2}{*}{ IBN259 } & \multirow[t]{2}{*}{ High-level } & MCT & Mup & 38 \\
\hline & & MCT & $\mathrm{Cd}, \mathrm{Hg}, \mathrm{Pi}, \mathrm{Eb}$ & 26 \\
\hline IBN259 & High-level & $\mathrm{C}$ & Mup & 38 \\
\hline \multirow[t]{4}{*}{ IBN260 } & \multirow[t]{4}{*}{ High-level } & $\mathrm{MCT}$ & Mup, Cm & $38,4.4$ \\
\hline & & MCT & Mup & 38 \\
\hline & & MCT & $\mathrm{Cm}$ & 4.4 \\
\hline & & MCT & $\mathrm{Cd}, \mathrm{Hg}, \mathrm{Pi}, \mathrm{Eb}$ & 26 \\
\hline \multirow[t]{3}{*}{ IBN260 } & \multirow[t]{3}{*}{ High-level } & $\mathrm{C}$ & Mup, Cm & $38,4.4$ \\
\hline & & $\mathrm{C}$ & Mup & 38 \\
\hline & & $\mathrm{C}$ & $\mathrm{Cm}$ & 4.4 \\
\hline \multirow[t]{2}{*}{ IBN267 } & \multirow[t]{2}{*}{ Low-level } & MCT & $\mathrm{Cd}, \mathrm{Hg}, \mathrm{Pi}, \mathrm{Eb}$ & 26 \\
\hline & & MCT & $\mathrm{Cm}$ & 4.4 \\
\hline IBN269 & Low-level & MCT & $\mathrm{Cd}, \mathrm{Hg}, \mathrm{Pi}, \mathrm{Eb}$ & 26 \\
\hline \multirow[t]{4}{*}{ IBN287 } & \multirow[t]{4}{*}{ High-level } & MCT & Mup, Cm & $38,4.4$ \\
\hline & & MCT & Mup & 38 \\
\hline & & MCT & $\mathrm{Cm}$ & 4.4 \\
\hline & & MCT & $\mathrm{Cd}, \mathrm{Hg}, \mathrm{Pi}, \mathrm{Eb}$ & 26 \\
\hline \multirow[t]{3}{*}{ IBN287 } & \multirow[t]{3}{*}{ High-level } & $\mathrm{C}$ & Mup, Cm & $38,4.4$ \\
\hline & & $\mathrm{C}$ & Mup & 38 \\
\hline & & $\mathrm{C}$ & $\mathrm{Cm}$ & 4.4 \\
\hline
\end{tabular}

$\mathrm{C}$, conjugation; $\mathrm{Cm}$, chloramphenicol; $\mathrm{Cd}$, cadmium; $\mathrm{Eb}$, ethidium bromide; $\mathrm{Hg}$, mercuric chloride; Mup, mupirocin; MCT, mixed-culture transfer; $\mathrm{Pi}$, propamidine isethionate.

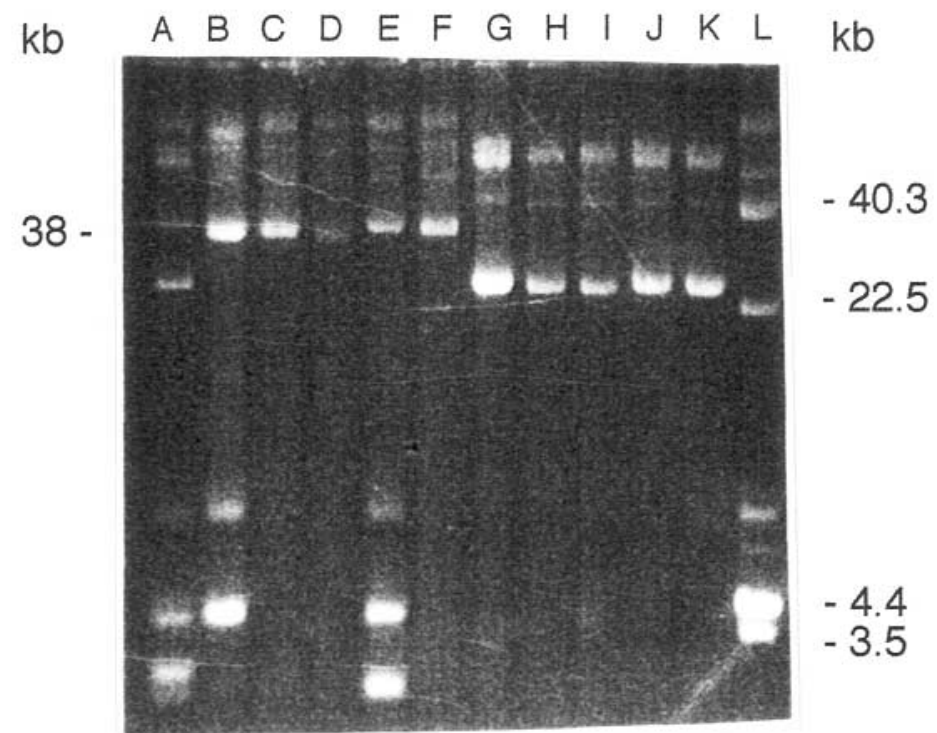

Fig. 2. Plasmids transferred in conjugation and MCT experiments. Lane A, isolate IBN246; B, a transconjugant of isolate IBN246 resistant to mupirocin and chloramphenicol carrying both $38-\mathrm{kb}$ and $4.4-\mathrm{kb}$ plasmids; C and D, mupirocin-resistant transconjugants of isolate IBN246 carrying only the $38-\mathrm{kb}$ plasmid; E, a mupirocin- and chloramphenicol-resistant transconjugant carrying 38 - and $4.4-\mathrm{kb}$ plasmids in addition to a $2.8-\mathrm{kb}$ cryptic plasmid; G$\mathbf{K}$, transcipients carrying the $26-\mathrm{kb}$ plasmid encoding resistance to cadmium, mercuric chloride, propamidine isethionate and ethidium bromide; L, S. aureus strain WBG4483 containing plasmid molecular size markers.

resistance were similar to those obtained in conjugation experiments (Table 2). The transfer of resistance to cadmium, mercuric chloride, propamidine isethionate and ethidium bromide was accompanied by the transfer of the 26-kb plasmid present in the donors (Fig. 2).

\section{PCR amplification of mupA DNA}

The 38-kb plasmids encoding high-level mupirocin resistance and genomic DNA from the low-level mupirocin-resistant isolates were used in PCR experiments to amplify the muрA DNA. Genomic DNA from 
isolates IBN287, XU320 and XU322 (IBN246 and IBN287 cured of high-level mupirocin resistance, respectively) were also tested. The results are summarised in Table 3, which also compares the mupirocin MICs and the genetic location of the mupirocin resistance determinant for each of the isolates. A PCR product of $1.6-\mathrm{kb}$ corresponding to the mup $A$ gene was detected in all the $38-\mathrm{kb}$ plasmids and from genomic DNA of isolate IBN287, but not from the low-level mupirocin-resistant isolates and XU320 (the mupirocin-susceptible derivative of isolate IBN246). Similarly, no amplified product was obtained with the genomic DNA of XU322, the low-level resistant derivative of isolate IBN287. Fig. 3 shows the electrophoretic pattern of the PCR products.

\section{Discussion}

This study investigated the genetic basis of antimicrobial resistance determinants in low- and high- level mupirocin-resistant MRSA isolated in a Burns Unit. The isolates were more resistant to ciprofloxacin and mupirocin and the majority had PFGE patterns that were different from MRSA isolated in the same unit in 1996-1997 [18], suggesting the introduction of a new MRSA clone. However, they had resistance and plasmid profiles similar to the 1996-1997 isolates. This is not surprising, as unrelated strains can harbour plasmids with the same resistance phenotype. Curing and transfer experiments demonstrated that the $26-\mathrm{kb}$ plasmid in these isolates coded for resistance to cadmium, mercuric chloride, propamidine isethionate and ethidium bromide, as shown earlier [5]. Similarly, the 4.4- and $38-\mathrm{kb}$ plasmids in the present isolates coded for chloramphenicol and high-level mupirocin resistance, respectively. The present isolates also carried 3.0- and 2.8-kb cryptic plasmids. These plasmids were considered to be cryptic because they could not be associated with any resistance determinant. Although the $3.0-$ and $2.8-\mathrm{kb}$ plasmids were cotransferred with the $38-\mathrm{kb}$ plasmid, the strains carrying them were resistant only to mupirocin. Moreover, when the $38-\mathrm{kb}$ plasmid was lost by curing, the resultant

Table 3. Location of mupA in mupirocin-resistant MRSA

\begin{tabular}{lrlc}
\hline Isolate no. & $\begin{array}{c}\text { Mupirocin } \\
\text { MIC }(\mathrm{mg} / \mathrm{L})\end{array}$ & $\begin{array}{l}\text { Location of } \\
\text { mupirocin resistance }\end{array}$ & $\begin{array}{c}\text { Presence } \\
\text { of }\end{array}$ \\
\hline IBN23 $A$
\end{tabular}

+ , present; -, not detected.

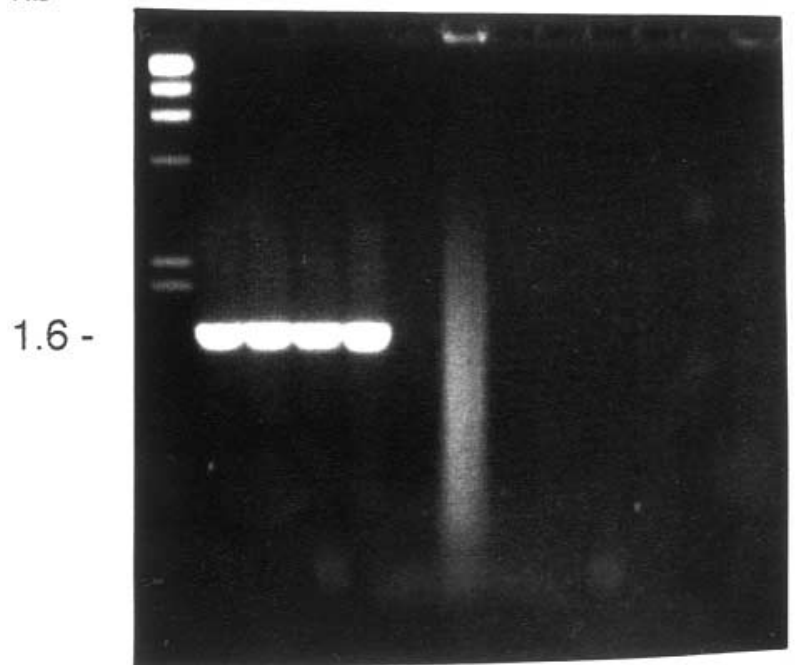

Fig. 3. PCR amplification of the mupA gene. Lane A, $\Phi$ lambda DNA digested with HindIII restriction endonuclease. The sizes in $\mathrm{kb}$ are from the top, 23.13, 9.4, $6.6,4.3,2.3,2.0$. Lanes $\mathbf{B}-\mathbf{E}$ contain amplified products from the $38-\mathrm{kb}$ plasmid DNA in: B, isolate IBN246; C, isolate IBN259; D, isolate IBN266; E, isolate IBN287. Lanes $\mathbf{F}-\mathbf{M}$, PCR products of genomic DNA from lowlevel mupirocin-resistant isolates: F, isolate IBN238; G, isolate IBN252; H, isolate IBN267; I, isolate IBN269; J, isolate IBN271; K, XU320; L, XU322; $\mathbf{M}$, WBG248. None of the low-level resistant or susceptible isolates contained the mupA gene.

mupirocin-susceptible strains still carrying the small plasmids were resistant only to novobiocin and rifampicin, which are the resistance markers of the recipient strain, XU21. These results indicated that resistance to methicillin, gentamicin, kanamycin, streptomycin, tetracycline, trimethoprim, ciprofloxacin, fusidic acid and mupirocin (low-level only) were located on the bacterial chromosome.

As the 38-kb high-level mupirocin resistance plasmid mediated its own transfer in conjugation experiments it fits the description of a conjugative plasmid. In addition, it co-transferred with the $4.4-\mathrm{kb}$ chloramphenicol resistance plasmid, as well as the $3.0-$ and $2.8-\mathrm{kb}$ cryptic plasmids, demonstrating its ability to mobilise non-conjugative plasmids. This is a new property of mupirocin resistance conjugative plasmids. Although staphylococcal gentamicin resistance $[19,20]$ and the cryptic $[21,22]$ conjugative plasmids have been known to mobilise non-conjugative plasmids, the conjugative mupirocin resistance plasmids have only recently been reported to mobilise non-conjugative plasmids $[10,11,15]$. Therefore, the $38-\mathrm{kb}$ plasmid belongs to a new class of mupirocin resistance conjugative plasmids that are capable of mobilising non-conjugative plasmids. In contrast, the $26-\mathrm{kb}$ plasmids are not conjugative plasmids and were not mobilised by the $38-\mathrm{kb}$ conjugative plasmid. In this regard, the $38-\mathrm{kb}$ mupirocin resistance plasmid shares the feature of mobilising only certain non-conjugative plasmids with other staphylococcal conjugative plasmids [20-22]. 
The 38-kb conjugative mupirocin resistance plasmid was also transferred in MCT experiments (Table 2), confirming a previous observation that conjugative plasmids can transfer under conditions for both conjugation and MCT (or phage-mediated conjugation) [10]. It has also been observed that non-conjugative plasmids can be transferred by a phage-mediated mechanism in conjugation experiments if the donor contains prophages $[10,23]$. Furthermore, the presence of prophages in the donor or recipient can increase the transfer frequencies of conjugative plasmids in conjugation experiments $[10,24]$. These observations are in contrast to an earlier suggestion that conditions which favour conjugative transfer of resistance plasmids would inhibit transfer by MCT and vice versa [25].

Until recently the mupA genes encoding high-level mupirocin resistance was found only on plasmids. Its detection in genomic DNA of isolates expressing lowlevel mupirocin resistance $[16,17]$ suggested that highand low-level mupirocin resistance may be mediated by the same genes, but their expression differed by virtue of their location and copy number. Alternatively, the mupA determinant may be carried on a transposable element like the gentamicin resistance transposon $\operatorname{Tn} 4001 / \operatorname{Tn} 3851$ that has been found on physically unrelated plasmids and on the bacterial chromosome in staphylococcal isolates [26]. The presence of the determinants for high- and low-level mupirocin resistance in the same isolate (IBN287) further raised the possibility that the muрA determinant maybe a transposable element. Leski et al. [4] have reported a similar finding in $S$. epidermidis. However, the failure to detect mupA genes in the genomic DNA of XU322 (isolate IBN287 cured of high-level resistance plasmid) indicated that the determinants for low-level and highlevel mupirocin resistance in this isolate were different. The тирA gene was not detected in the genomic DNA of any of the low-level mupirocin-resistant isolates. Similarly, Schmitz et al. [27] did not detect the mupA gene in low-level mupirocin-resistant isolates that they studied. Therefore more studies are needed to establish whether the observed chromosomal muр $A[16,17]$ is widespread in staphylococci from different geographical regions or whether it is due to the transposition of the тир $A$ determinant or the integration of a mupirocin resistance plasmid into the bacterial chromosome in those isolates.

This study was supported by project grant MI 091 and MI 111 from Kuwait University Research Administration.

\section{References}

1. Cookson BD. The emergence of mupirocin resistance: a challenge to infection control and antibiotic prescribing practice. J Antimicrob Chemother 1998; 41: 11-18.

2. Vasquez JE, Walker ES, Franzus BW, Overbay BK, Reagan
DR, Sarubbi FA. The epidemiology of mupirocin resistance among methicillin-resistant Staphylococcus aureus at a Veterans' Affairs hospital. Infect Control Hosp Epidemiol 2000; 21: 459-464.

3. Schmitz F-J, Lindenlauf E, Hoffmann B et al. The prevalence of low- and high-level mupirocin resistance in staphylococci from 19 European hospitals. J Antimicrob Chemother 1998; 42: 489-495.

4. Leski TA, Gniadkowski M, Skoczyńska A, Stefaniuk E, Trzciński K, Hryniewicz W. Outbreak of mupirocin-resistant Staphylococci in a hospital in Warsaw, Poland, due to plasmid transmission and clonal spread of several strains. $J$ Clin Microbiol 1999; 37: 2781-2788.

5. Udo EE, Farook VS, Mokadas EM, Jacob LE, Sanyal SC. Molecular fingerprinting of mupirocin-resistant methicillinresistant Staphylococcus aureus from a burn unit. Int $J$ Infect Dis 1999; 3: 82-87.

6. Rahman M, Connolly S, Noble WC, Cookson B, Phillips I. Diversity of staphylococci exhibiting high-level resistance to mupirocin. J Med Microbiol 1990; 33: 97-100.

7. Morton TM, Johnston JL, Patterson J, Archer GL. Characterization of a conjugative staphylococcal mupirocin resistance plasmid. Antimicrob Agents Chemother 1995; 39: 1272-1280.

8. Needham C, Rahman M, Dyke KGH, Noble WC. An investigation of plasmids from Staphylococcus aureus that mediate resistance to mupirocin and tetracycline. Microbiology 1994; 140: 2577-2583.

9. Udo EE, Pearman JW, Grubb WB. Emergence of mupirocin resistance in methicillin-resistant Staphylococcus aureus in Western Australia. J Hosp Infect 1994; 26: 157-165.

10. Udo EE, Jacob LE. Conjugative transfer of high-level mupirocin resistance and the mobilization of non-conjugative plasmids in Staphylococcus aureus. Microb Drug Resist 1998; 4: 185-193.

11. Pawa A, Noble WC, Howell SA. Co-transfer of plasmids in association with conjugative transfer of mupirocin or mupirocin and penicillin resistance in methicillin-resistant Staphylococcus aureus. J Med Microbiol 2000; 49: 1103-1107.

12. Gilbart J, Perry CR, Slocombe B. High-level mupirocin resistance in Staphylococcus aureus: evidence for two distinct isoleucyl-tRNA synthetases. Antimicrob Agents Chemother 1993; 37: 32-38.

13. Dyke KGH, Curnock SP, Golding M, Noble WC. Cloning of the gene conferring resistance to mupirocin in Staphylococcus aureus. FEMS Microbiol Lett 1991; 77: 195-198.

14. Hodgson JE, Curnock SP, Dyke KGH, Morris D, Sylvester DR, Gross MS. Molecular characterization of the gene encoding high-level mupirocin resistance in Staphylococcus aureus J2870. Antimicrob Agents Chemother 1994; 38: 1205-1208.

15. Udo EE, Jacob LE, Mokadas EM. Conjugative transfer of high-level mupirocin resistance from Staphylococcus haemolyticus to other Staphylococci. Antimicrob Agents Chemother 1997; 41: 693-695.

16. Ramsey MA, Bradley SF, Kauffman CA, Morton TM. Identification of chromosomal location of mupA gene encoding low-level mupirocin resistance in Staphylococcal isolates. Antimicrob Agents Chemother 1996; 40: 2820-2823.

17. Ramsey MA, Bradley SF, Kauffman CA, Morton TM, Patterson JE, Reagan DR. Characterization of mupirocinresistant Staphylococcus aureus from different geographic areas. Antimicrob Agents Chemother 1998; 42: 1305.

18. Udo EE, Jacob LE, Mathew B. The spread of a mupirocinresistant MRSA clone in Kuwait hospitals. Program of the First International Congress of Infectious and Tropical Diseases, Muscat, Oman, 2000.

19. Townsend DE, Bolton S, Ashdown N, Grubb WB. Transfer of plasmid-borne aminoglycoside-resistance determinants in staphylococci. J Med Microbiol 1985; 20: 169-185.

20. Projan SJ, Archer GL. Mobilization of the relaxable Staphylococcus aureus plasmid pC221 by the conjugative plasmid pGO1 involves three pC221 loci. J Bacteriol 1989; 171: $1841-1845$.

21. Udo EE, Grubb WB. Transfer of resistance determinants from a multi-resistant Staphylococcus aureus isolate. J Med Microbiol 1991; 35: 72-79.

22. Udo EE, Love H, Grubb WB. Intra- and inter-species mobilisation of non-conjugative plasmids in staphylococci. $J$ Med Microbiol 1992; 37: 180-186.

23. Pereira MSV, Barreto VP, Siqueira-Junior JP. Phage-mediated 
transfer of tetracycline resistance in Staphylococcus aureus isolated from cattle in Brazil. Microbios 1997; 92: 147-155.

24. Zueva VS, Nesterenko LN, Dmitrenko OA, Akatov AK. Lysogeny of methicillin-resistant Staphylococcus aureus and the role of prophages in transfer of conjugative and nonconjugative plasmids. J Chemother 1991; 3: 279-282.

25. Townsend DE, Bolton S, Ashdown N, Grubb WB. Comparison of phage-mediated and conjugative transfer of staphylococcal plasmids in vitro and in vivo. $J$ Med Microbiol 1986; 22: $107-114$.

26. Lyon BR, Skurray R. Antimicrobial resistance of Staphylococcus aureus: genetic basis. Microbiol Rev 1987; 51: 88-134.

27. Schmitz FJ, Fluit AC, Lindenlauf E, Scheuring S, Kohrer K. Molecular analyses of possible mechanisms coding for lowlevel mupirocin resistance in clinical Staphylococcus aureus isolates. Eur J Clin Microbiol Infect Dis 2000; 19: 649-650. 